\title{
Biochemical changes in seeds of five cotton genotypes stored in different packaging materials at ambient condition
}

\begin{abstract}
Variation in the biochemical attributes of the seeds from five genotypes (CB-8, SR-08, BC-0125, BC-0236 and BC-0252) of cotton (Gossypium hirsutum L.) was appraised. Seeds were packed in polythene and cloth bag and stored over 14 months to determine the changes in biochemical composition under ambient condition. Results revealed that total soluble sugar, total soluble protein and oil content of cotton seeds decreased and total free amino acid increased with the increase of storage period. However, decreasing rate of total soluble sugar, total soluble protein and oil content and increasing rate of total free amino acid was slower in polythene bag and faster in cloth bag throughout the storing period. Among the genotypes, BC-0252 showed slower degradation of biochemical composition of stored seeds than that of seeds of other genotypes.
\end{abstract}

Keywords: cotton genotype, storage container, total free amino acid, total soluble sugar, total soluble protein, oil content
Volume 8 Issue 2 - 2018

\author{
M Abdus Salam,' M Moynul Haque, ${ }^{2}$ Md \\ Obaidul Islam, ${ }^{3}$ M Nasir Uddin, ${ }^{4}$ Md Nazmul \\ Haque $^{3}$ \\ 'Cotton Development Board, Zonal office, Chuadanga, \\ Bangladesh \\ ${ }^{2}$ Department of Agronomy, Faculty of Agriculture, Bangabandhu \\ Sheikh Mujibur Rahman Agricultural University, Bangladesh \\ ${ }^{3}$ Department of Agronomy, Faculty of Agriculture, Sher-e-Bangla \\ Agricultural University, Bangladesh \\ ${ }^{4}$ Genetic Resources and Seed Division, Bangladesh Jute \\ Research Institute, Bangladesh
}

\begin{abstract}
Correspondence: Md Nazmul Haque, Department of Agronomy, Faculty of Agriculture, Sher-e-Bangla Agricultural University, Sher-e-Bangla Nagar, Dhaka-1207, Bangladesh, Email sumon2539@gmail.com
\end{abstract}

Received: September 08, 2017 | Published: April 26, 2018

\section{Introduction}

Cotton (Gossypium hirsutum L.) being a native to tropical and subtropical regions is the most important fiber/food crop in the world. It is also considered as the second best potential source for plant proteins after soybean and the fifth prominent oil-producing crop after soybean, palm, canola and sunflower. ${ }^{1-5}$ The utilization of plant proteins to supplement diet has been receiving increased attention partly due to the expanding demand on dietary proteins around the world. An important source of these plant proteins is the protein by-product of oilseed after the oil has been extracted for industrial utilization. Cotton seed is an important oil seed to provide the protein by-product because of the enormous amount of cotton seeds required for fiber production. ${ }^{6}$ Cotton is regarded as one of the important conventional oilseed crops with potential to bridge the existing gap between the supply and domestic demand of vegetable oils. ${ }^{7}$ Oil and protein content of cotton seeds changes between $12-25 \%$ and $24 \%$, respectively ${ }^{8,9}$ Technically, cotton seed oil is a good source of an essential fatty acid (linoleic acid, C18:2) as well as contains reasonable amount of oleic acid. ${ }^{10}$ The oil has good oxidative stability due to its high antioxidant tocopherol contents and oleic acid., ${ }^{71}$ As far as the industrial uses of cotton seed oil are concerned, this oil is in use for preparation of alkyl resins for interior paints, special biolubricants and soft soaps. ${ }^{12}$ The oil has also been explored as a feedstock for biodiesel production. ${ }^{13}$ It is commonly accepted that the amount and oil yield varies depending on genotype, agro climatic and geographic factors and storage conditions. ${ }^{14-17}$ Seed quality is regulated during production, processing and storage. During storage, it is known that reduction in physiological quality of seed is related to biochemical alterations of aged seed. Likhatchev et al. ${ }^{18}$ found reduced concentrations of soluble sugars during ageing of seeds of some plant species. Cotton seeds have greater propensity to deterioration due to their high oil content and special care is needed to maintain their viability and vigour during storage. However, information relating biochemical changes associated with cotton seed deterioration during storage yet is not fully known. The present study, therefore, was designed with the prime objective to determine the changes in biochemical composition of selected genotypes of cottonseeds cultivated in Bangladesh stored over time at ambient condition.

\section{Materials and methods}

\section{Experimental site}

The experimental work was conducted at the Seed Science and Technology Unit laboratory of Bangabandhu Sheikh Mujibur Rahman Agricultural University, Gazipur $\left(24.09^{\circ} \mathrm{N}\right.$ and $\left.90.25^{\circ} \mathrm{E}\right)$, Bangladesh during the period of May, 2009 to July, 2010.

\section{Experimental materials and design}

Freshly harvested one hundred seeds of five cotton genotypes viz., CB-8, SR-08, BC-0125, BC-0236 and BC-0252 were stored at ambient condition for 14 months by using two packaging materials i.e., hermetically sealed polythene bag (thickness $8 \mu$ ) and cloth bag. The seeds were ground with the help of a mini grinding mill and this grounded seed samples were used to determine the biochemical composition of seed once after harvest and then 7 and 14 months of storage. Seeds of five cotton genotypes were sown in a randomized complete block design with three replications.

\section{Determination of total soluble sugar}

Total soluble sugar content in the seeds was estimated following anthrone-sulphuric acid method. ${ }^{19}$ 


\section{Determination of total soluble proteins}

Total soluble proteins were measured according to method of Lowry et al. ${ }^{20}$ where seed extracts were made following the method of Kalpana \& Madhava. ${ }^{21}$

\section{Determination of total free amino acids}

Total free amino acids were determined according to the method of Moore \& Stein. ${ }^{22}$

\section{Determination of oil percentage}

Oil percentage was measured following Gadgil et al. ${ }^{23}$ who estimated oil percentage from moisture-free seed meal by solvent extraction using other petroleum ether (boiling point $60^{\circ} \mathrm{C}$ to $80^{\circ} \mathrm{C}$ ) in a Soxhlet apparatus for eight hours. The meal was pre-dried $\left(60^{\circ} \mathrm{C}\right.$; 24 hours) and two grams of meal was used for the estimation of oil. No further oil was recovered from the residue after eight hours of refluxing.

\section{Statistical analysis}

The data were subjected to analysis of variance (ANOVA), and the mean differences were compared by least significant difference (LSD) test using MSTAT-C. ${ }^{24}$ Differences at $\mathrm{p} \leq 0.05$ were considered significant.

\section{Results and discussion}

\section{Total soluble sugar}

Total soluble sugar of freshly harvested cotton seed was significantly different (Table 1) which ranged from 11.37 to $12.45 \%$. Lawhon et al. $^{25}$ found total sugar ranged from 5.9 to $9.2 \%$ in undefeated kernels and 11.40 to $16.90 \%$ in defatted flour of cotton seed from 16 cotton varieties which are in agreement with the findings of the present study. The highest total soluble sugar $\left(124.50 \mathrm{mg} \mathrm{g}^{-1}\right)$ was determined from the seeds of the genotype $\mathrm{BC}-0252$ and it was the lowest $\left(113.70 \mathrm{mg} \mathrm{g}^{-1}\right)$ in the seeds of the genotype BC-0236. $\mathrm{t}$ is seen that total soluble sugar of cotton seed progressively declined with the increase of storage period (Figure 1) which might be due to age induced limitation of respiratory substrates.$^{26}$ Limitation of respiratory substrates may lessen the ability of seeds to maintain the vitrified state, a non-crystalline liquid state of high viscosity. ${ }^{27}$ The high viscosity of the glassy state would be expected to have a retarding effect on deteriorative reactions in the cytoplasm and thus the glassy state may be considered to be a biophysical barrier for seed deterioration. ${ }^{28}$ On the contrary, the loss of the glassy state would dramatically decrease the cytoplasm viscosity and thus increase molecular mobility. ${ }^{29}$ and as a result, deteriorative reactions in seeds should be expected to occur more rapidly. However, decline in total soluble sugar was pronounced in seeds of cloth bag condition compared to polythene bag which may be attributed to higher temperature and relative humidity prevailed in ambient environment that enhanced rapid depletion of reserved carbohydrates for supporting increased respiratory metabolism during storage ${ }^{30}$ Similar results were also reported by Yaklich ${ }^{31}$ in Soybean seeds; Murthy and $\mathrm{Sun}^{32}$ in corn and Cieslak et al. ${ }^{33}$ in different cereal seeds.

\section{Total soluble protein}

Total soluble protein of cotton seed differed significantly among the genotypes at the time of storing and it ranged from 19.82 to
$26.76 \%$ (Table 1). The highest total soluble protein $\left(267.61 \mathrm{mg} \mathrm{g}^{-1}\right)$ was estimated from the seeds of the genotype CB-8 and it was lowest $\left(198.17 \mathrm{mg} \mathrm{g}^{-1}\right)$ in the seeds of the genotype SR-08. This result similar with the findings of Sharma et al. ${ }^{34}$ who found total protein ranged from 25.60 to $34.80 \%$ in nine cotton genotypes. During storage, protein content of seeds of cotton genotypes declined progressively over time (Figure 2). The rate of decrease of soluble protein was higher in seeds of cloth bag compared to polythene bag under ambient condition over during 14 months of storage. Similar results were found in case of other varieties of cotton seed. ${ }^{35}$ The decline in total soluble protein content with ageing is also associated with the rates of protein synthesis, degradation or both depending upon the tolerance of genotypes to ageing. Pukacka and Ratajczak ${ }^{36}$ observed an increased production of reactive oxygen species (ROS) during storage that can degrade soluble protein and diminish enzyme activities and the content of late embryogenesis abundant (LEA)-like proteins or small heat shock proteins (sHSPs). These proteins may play a protective role to maintain long storage life of dry seeds. ${ }^{37}$ In present study, faster decline of protein content in cloth bag during storage might be attributed to increase in respiratory enzymes at higher temperature and relative humidity under ambient storage conditions.

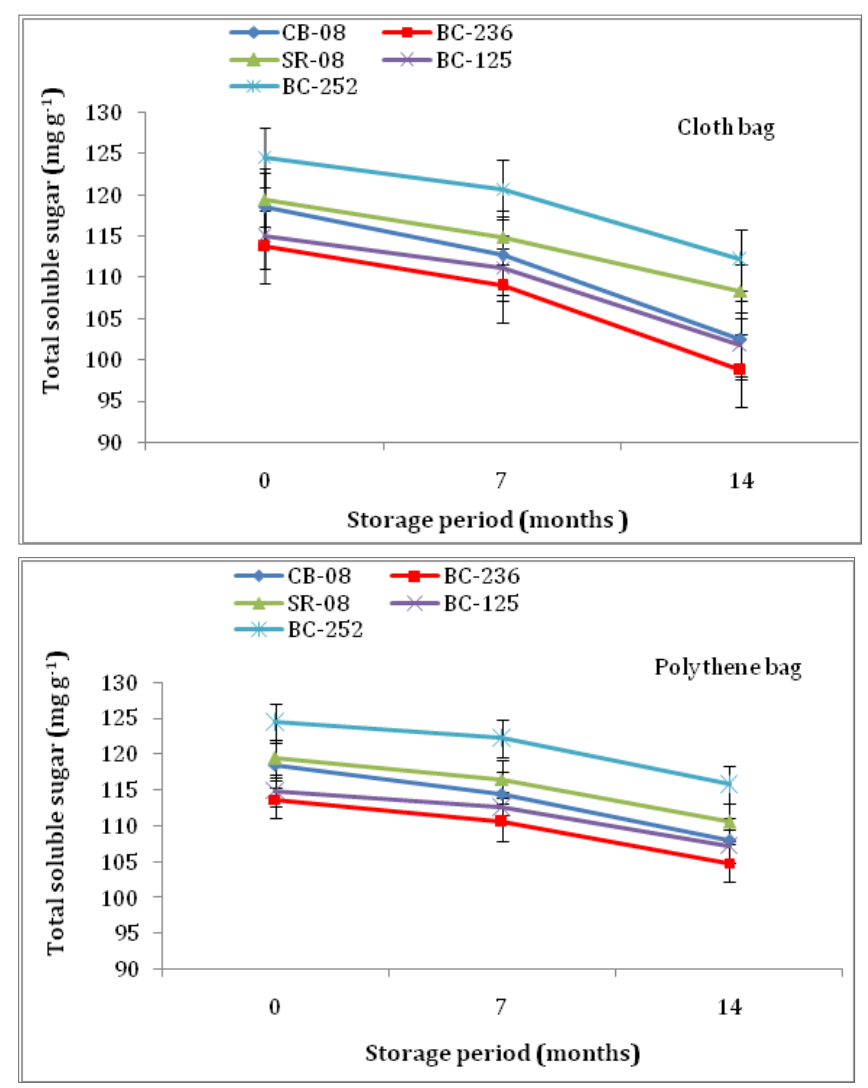

Figure I Effect of storage containers on the total soluble sugar content in the seeds of cotton genotypes. Mean $( \pm S D)$ was calculated from three replicates for each treatment.

\section{Total free amino acid}

Differences in total free amino acid of seeds of different cotton genotypes were found at the time of storing at ambient condition (Table 1). The highest total free amino acid $\left(44.00 \mathrm{mg} \mathrm{g}^{-1}\right)$ was estimated from the seeds of the genotype BC-0125 and the lowest $\left(27.10 \mathrm{mg} \mathrm{g}^{-1}\right)$ 
was obtained from the seeds of BC-0252 genotype. Such differences between the genotypes in free amino acid composition also reported by Khattab et al. ${ }^{38}$ in some cotton seeds species. Total free amino acid in stored cotton seed increased progressively over the storage and it was higher in seeds of cloth bag as compared to polythene bag under ambient condition (Figure 3). Decrease in protein content is the resultant of the increase of free amino acid. This means that with the increase of free amino acid total protein content decreases. This result agrees with the findings of Sukesh \& Chandrashekar ${ }^{39}$ who observed that the total free amino acids increased with ageing of seeds and the increased amino acid content was the resultant of the breaking of soluble protein. The changes in free amino acid and soluble protein of cotton seed of different cotton genotypes during storage also agree with the findings of Sreeramulu $u^{40}$ in groundnut and Basavarajappa et al. ${ }^{41}$ in Maize.

Table I Total soluble sugar, protein, free amino acid and oil content in the seeds of cotton genotypes at the time of storing

\begin{tabular}{lllll}
\hline Genotype & Total soluble sugar $\left(\mathbf{m g ~ g}^{-1}\right)$ & Total soluble protein $\left(\mathbf{m g ~ g}^{-1}\right)$ & $\begin{array}{l}\text { Total free amino acid }(\mathbf{m g} \\
\left.\mathbf{g}^{-1}\right)\end{array}$ & Oil content $(\%)$ \\
\hline CB-8 & $1 / 8.5$ & 267.61 & 32.6 & 18.39 \\
SR-08 & 119.4 & 198.17 & 31.1 & 17.74 \\
BC-0125 & $1 \mid 4.9$ & 205.63 & 44 & 18.46 \\
BC-0236 & $1 \mid 3.7$ & 229.54 & 42.2 & 17.84 \\
BC-0252 & 124.5 & 252.08 & 27.1 & 18 \\
LSD $_{(0.05)}$ & 10.64 & 8.09 & 5.23 & $\mathrm{~ns}$ \\
\hline
\end{tabular}

Mean $( \pm S D)$ was calculated from three replicates for each treatment; ns: non-significant

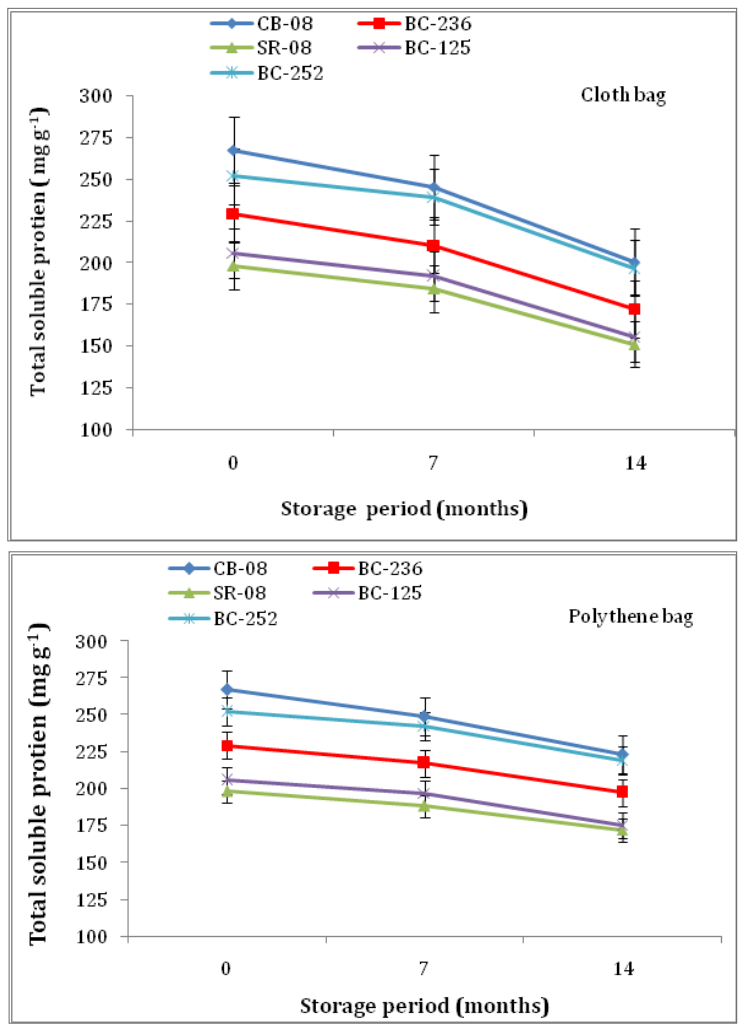

Figure 2 Effect of storage containers on the total soluble protein content in the seeds of cotton genotypes. Mean $( \pm S D)$ was calculated from three replicates for each treatment.
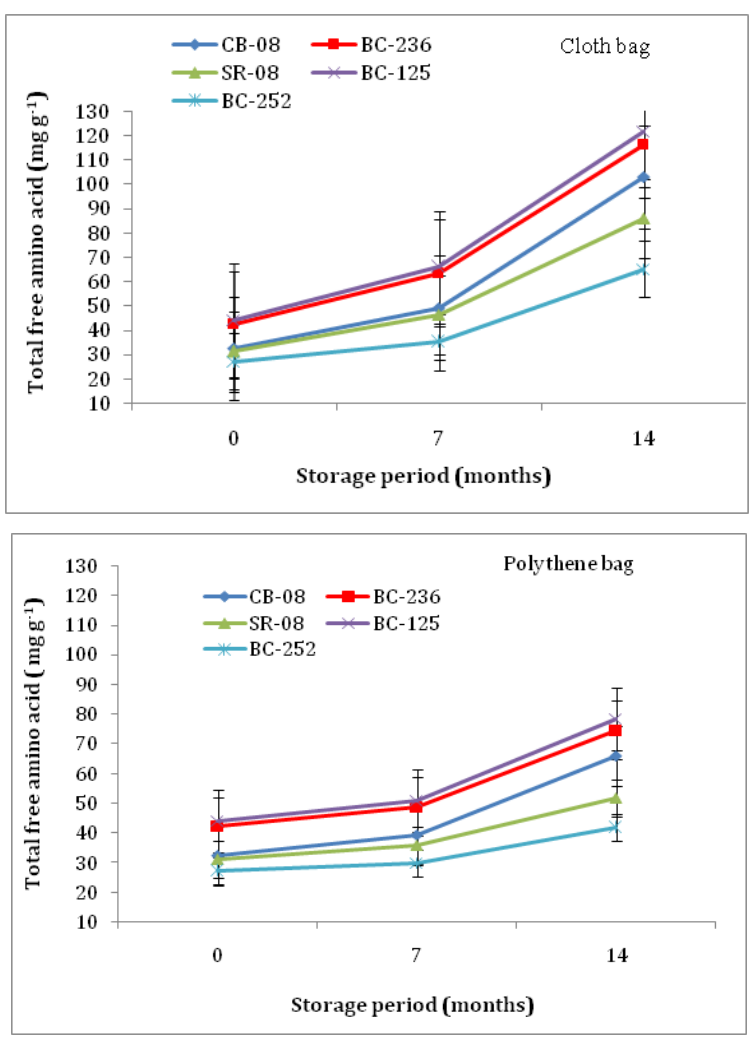

Figure 3 Effect of storage containers on the total free amino acid in the seeds of cotton genotypes. Mean $( \pm S D)$ was calculated from three replicates for each treatment. 


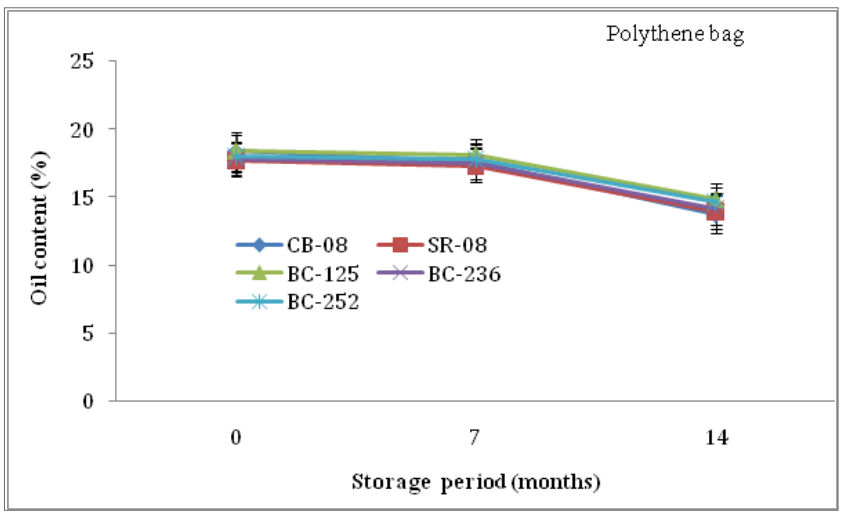

Figure 4 Effect of storage containers on the oil content in the seeds of cotton genotypes. Mean $( \pm S D)$ was calculated from three replicates for each treatment.

\section{Oil content}

Oil content in the seeds of different cotton genotypes did not show significant variation at the time of storing at ambient condition (Table 1). Numerically the highest oil content $(18.46 \%)$ was determined in BC-0125 genotype and the lowest (17.74\%) was noticed in genotype SR-08. The mean oil content that observed in this study was similar to those reported by others in cotton..$^{42}$ Agarwal et al..$^{43}$ also found 12.40 to $25.20 \%$ oil in 41 phenotypic ally diverse genotypes of upland cotton. Oil content of cotton seeds of different genotypes declined with the increase of storage period irrespective of the containers (Figure 4). The rate of decrease of oil content was faster in the seeds of cloth bag and slower in the seeds of polythene bag at ambient condition as obtained by Raikar et al. ${ }^{35}$ in cotton seeds. Oil content declined with passing of time may be due to lipid peroxidation which is considered as one of the major cause of seed deterioration in storage. Lipid peroxidation causes depletion of lipid reserves resulting in production of free fatty acids, ${ }^{44}$ enzyme degradation and inactivation, ${ }^{45}$ loss of membrane integrity ${ }^{44}$ and production of highly reactive free radicals intermediates ${ }^{46}$ and finally reduces seed viability. The faster rate of declining oil content of seed in cloth bag ambient condition might be attributed to faster degradation in oil content under the condition of temperature fluctuation and high relative humidity. The results agree with the findings of Donald \& Jacobs ${ }^{47}$ in Pinus species and Stolyhwo $\& \mathrm{Jason}^{48}$ in seed of Norway spruce.

\section{Conclusion}

Our results showed that total soluble sugar, soluble protein and free amino acid of cotton seed differed significantly among the genotypes at the time of storing although oil content of different genotypes did not varied significantly. In storage, total soluble sugar, protein content and oil content of seeds of cotton genotypes declined progressively over time but free amino acid increased. Degradation of biochemical composition was least in seed of BC-0252 in storage and thus this genotype may be considered as potential source for enhancement of cotton seed quality in Bangladesh. The results of this study might be useful for selection and cultivation of an appropriate cotton genotype in the specific areas with the purpose of gaining maximum nutritional benefits.

\section{Acknowledgements}

None.

\section{Conflict of interest}

The authors declare there is no conflict of interest.

\section{References}

1. Sawan MZ, Hafeez BSAE, Alkassas R, et al. Cottonseed, protein, oil yields and oil properties as affected by nitrogen fertilization and foliar application of potassium and a plant growth retardant. World Journal of Agricultural Sciences. 2006;2(1):56-65.

2. Ahmad S, Anwar F, Hussain AI, et al. Dose soil salinity affect yield and composition of cottonseed oil? Journal of the American Oil Chemists' Society. 2007;84(9):845-851.

3. Wang K, Wang Z, Li F, et al. The draft genome of a diploid cotton Gossypium raimondii. Nature Genetics. 2012;44(10):1098-1103.

4. Shi J, Chinn MS, Sharma-Shivappa RR. Interactions between fungal growth, substrate utilization, and enzyme production during solid substrate cultivation of Phanerochaete chrysosporium on cotton stalks. Bioprocess Biosyst Eng. 2014;37(12):2463-2473.

5. Oliveira MA, Duarte JB, Morello CL, et al. Mixed inheritance in the genetic control of ramulosis (Colletotrichum gossypii var. cephalosporioides) resistance in cotton. Genet Mol Res. 2016;15:1-6.

6. Cater CM, Mattil KF, Meinke WW, et al. Cottonseed protein food products. J Am Oil Chem Soc. 1977;54(2):90-93.

7. Sekhar SC, Rao BVK. Cottonseed oil as health oil. Pertanika J Trop Agric Sci. 2011;34(1):17-24.

8. Kohel RJ. Cotton improvement, evaluation of near infrared reflectance for oil content of cottonseed. The Journal of Cotton Science. 1998;2:23-26.

9. Mert M, Akiscan Y, Gencer O. Inheritance of oil and protein content in some cotton generations. Journal of Plant Sciences. 2004;3(2):174-176.

10. Brien O, Jones LA, King CC, et al. In: Bailey's Industrial Oil and Fat Products. John Wiley \& Sons. 2005.

11. Brien RD, Farr WR, Wan PJ. Introduction to Fats and Oil Technology. Illinois: American Oil Chemists Society; 2000.

12. Saxena DK, Shsharand SK, Sambi SS. Comparative extraction of cottonseed oil by n-hexane and ethanol. J ARPN Journal of Engineering and Applied Sciences. 2011;6(1):84-89.

13. Rashid U, Anwar F, Knothe G. Evaluation of biodiesel obtained from cottonseed oil. Fuel Processing Technology. 2009;90(9):1157-1163.

14. Baydar H, Turgut I. Variations of fatty acid composition according to some morphological and physiological properties and ecological regions in oilseed plants. Turkish Journal of Agriculture and Forestry. 1999;23(1):81-86.

15. Bambawale OM, Singh A, Sharma OP, et al. Performance of Bt cotton (MECH-162) under integrated pest management in farmers' participatory field trial in Nanded district, Central India. Current Science. 2004;86(12):1628-1633.

16. Figueiredo AC, Barroso JG, Pedro LG, et al. Factors affecting secondary metabolite production in plants: volatile components and essential oils. Flavour and Fragrance Journal. 2008;23(4):213-226.

17. Reddy BS, Aruna E. Effects of irrigation levels through drip on growth, yield and quality of cotton. African Journal of Biotechnology. 2009;23(1):56-59. 
18. Likhatchev BS, Zelensky GY, Kiashko YG, et al. Modeling of seed ageing. Seed Sci Technol. 1984;12:385-393.

19. Shirlaw DW, Grlchrist DW. A practical course in agricultural chemistry. A volume in The Commonwealth and International Library: Agriculture and Forestry Division. 1967;122-130 p.

20. Lowry OH, Rosebrough NJ, Farr AL, et al. Protein measurement with the Folin phenol reagent. J Biol Chem. 1951;193(1):265-275.

21. Kalpana R, Madhava Rao KV. Protein metabolism of seeds of pigeon pea cultivars during accelerated ageing. Seed Sci Technol. 1997;25:271-279.

22. Moore S, Stein WH. Photometric nin-hydrin method for use in the chromatography of amino acids. J Biol Chem . 1948;176(1):367-387.

23. Gadgil JD, Susselan KN, Mitra R, et al. Chemical composition of seed and electrophoretic pattern of seed storage protein of jute Corchorus olitorious and Corchorus capsularis. Seed Sci Technol. 1989;17(3):499-506.

24. Gomez KA, Gomez AA. Statistical Procedures for Agricultural Research. 2nd ed. New York: An Wiley International Science Publication; 1984.

25. Lawhan JT, Cater CM, Mattil KF. Evaluation of the food use potential of sixteen varieties of cottonseed. Journal of the American Oil Chemists' Society. 1977;54(2):75-80.

26. Petruzelli L, Taranto G. Wheat ageing: the contribution of embryonic and non-embryonic lesion to loss seed viability. Plant Physiol. 1989;76(3):289-294.

27. Bruni F, Leopold AC. Glass transitions in soybean seed: relevance to anhydrous biology. Plant Physiol. 1991;96(2):660-663.

28. Sun WQ, Leopold AC. Glassy state and seed storage stability: a viability equation analysis. Annals of Botany. 1994;74(6):601-604.

29. Williams ML, Landel RF, Ferry JD. The temperature dependence of relaxation mechanisms in amorphous polymers and other glass-forming liquids. J American Chem Soc. 1955;77(14):3701-3707.

30. Baki AA, Anderson JD. Viability and leaching of sugars from germinating barley. Crop Sci. 1970;10(1):31-34.

31. Yaklich RW. Effect of aging on soluble oligosaccharide content in soybean seeds. Crop Sci. 1985;25(4):701-704.

32. Murthy UMN, Sun WQ. Protein modification by the Amadori and Maillard reactions during seed storage: roles of sugar hydrolysis and lipid peroxidation. J Exp Bot. 2000;51(348):1221-1228.

33. Cieslak PAI, Niedzielski M, Michalczyk DJ, et al. Soluble carbohydrates in cereal (wheat, rye, triticale) seed after storage under accelerated ageing conditions. Acta Societatis Botanicorum Polaniae. 2010;79(1):21-25.

34. Sharma D, dharminder P, Atwal AK, et al. Genetic variation for some chemical and biochemical characteristics in cotton seed oil. $J$ Cotton Res Dev. 2009;23(1):1-7.
35. Raikar SD, Kulkarni GN, Shashidhar SD, et al. Effect of delinting, seed treatment and packaging material on the change of composition in cotton seed during storage. Karnataka J Agric Sci. 2006;19(1):24-26.

36. Pukacka SD, Ratajczak E. Age-related biochemical changes during storage of beech (Fagus sylvatica L.) seeds. Seed Sci Res. 2007;17(1):45-53.

37. Wolkers WF, McCready S, Brandt WF, et al. Isolation and characterization of a D-7 LEA protein from pollen that stabilizes glasses in vitro. Biochim Biophys Acta. 2001;1544(1-2):196-206.

38. Khattab AH, Khalifa H, Tinay AHEL. Chemical composition of seeds of some species of the genus Gossypium. J Agric Sci. 1977;88(1):55-59.

39. Sukesh SH, Chandrashekar KR. Biochemical changes during the storage of seeds of Hopea ponga (Dennst.) Mabberly: An Endemic Species of Western Ghats. Res J Seed Sci. 2011;4:106-116.

40. Sreeramulu N. Germination and food reserves in bambarra groundnut seeds (Voandzeia subterranea Thouars) after different periods of storage. $J$ Exp Bot. 1983;34(138):27-33.

41. Basavarajappa BS, Shetty HS, Prakash HS. Membrane deterioration and other biochemical changes associated with accelerated ageing of maize seeds. Seed Sci. Technol. 1991;19(2):279-286.

42. Lukonge E, Labuschagne MT, Hugo A. The evaluation of oil and fatty acid composition in seed of cotton accessions from various countries. $J \mathrm{Sci}$ Food Agric. 2006;87(2):340-347.

43. Agarwal DK, Singh P, Kate N, et al. Inter-relationship among seed oil traits in upland cotton (Gossypium hirsutum). J Cotton Res Dev. $2003 ; 17: 219-220$

44. Basra SMA, Ahmad N, Khan MM, et al. Assesment of cotton seed deterioration during accelerated ageing. Seed Sci Technol. 2003;31:531540

45. Hsu CC, Chen CL, Chen JJ, et al. Accelerated aging-enhanced lipid peroxidation in bitter gourd seeds and effects of priming and hot water soaking treatments. Scientia Horticulturae. 2003;98(3):201-212.

46. Freits RA, Dias DCFS, Oliveira MGA, et al. Physiological and biochemical changes in naturally and artificially aged cotton seeds. Seed Sci Technol. 2006;34(2):253-264.

47. Donald DGM, Jacobs CB. The effect of storage time, temperature and container on the viability in the seeds of four pine species. South African Forestry Journal. 1990;154(1):41-46.

48. Stolyhwo A, Janson H. Contents of lipids and fatty acid composition in Norway Spruce (Picea abies) seeds during long term storage. Prace Inst Badawezego Lesnictwa Serial. 1999;874(877):5-18. 